Rosen, Ilana. "Tripping over the Dead: Hungarian-Israeli Holocaust Survivor Women's Narratives of Immigration, Restoration, and Remembrance.” AHEA: E-journal of the American Hungarian Educators Association, Volume 5 (2012): http://ahea.net/ejournal/volume-5-2012

\title{
Tripping over the Dead: Hungarian-Israeli Holocaust Survivor Women's Narratives of Immigration, Restoration, and Remembrance
}

\author{
Ilana Rosen, Ben Gurion University of the Negev, Israel
}

\begin{abstract}
This essay focuses on the post-Holocaust, Israeli life of five female narrators of Hungarian origin as expressed in their inclusive life histories. A close reading of the later period in the life histories of the five women exposes how they experienced and view their post-Holocaust life as Holocaust survivors and new immigrants in a newly founded State. The women's narratives of finding housing, work, and starting new families show that despite practical hardship they look back on it all with humor, acceptance, and optimism. The women's narratives about the recurrence of Holocaust-related bad memories, nightmares, fears, and worries illustrate that the past is always present and shakes the stability of their post-Holocaust, seemingly rehabilitated lives. This instability or proneness to belated agony is even stronger for two women, who embark on journeys to their past Hungarian hometowns (accompanied by their husbands, likewise of Hungarian origin). The hometown visit narratives are compelling, bothering, and carry a nightmarish quality. Seen against the background of the five women's former Hungarian lives and identity, the narratives of emigration, remembering, and re-visiting clarify that all these experiences are shadowed by the women's Holocaust experiences. Yet, while their later lives offer them some consolation, the memory of the Nazi camps as that of the Hungarian scenes/sites of deportation to Auschwitz, are forever painful and poignant.
\end{abstract}

Keywords: life history, personal narrative, Holocaust, Jewish studies, women studies, emigration, nation building, trauma, hometown visits.

Biography: Ilana Rosen is Associate Professor of Hebrew Literature at the Ben Gurion University of the Negev at Beer Sheva, Israel. She studies documentary literature, or non-fictional prose, of Jews of CentralEastern Europe, with stress on their Holocaust memory and narrative, as well as the multi-ethnic narrative of emigration to and foundation of the south of Israel. Her publications include: Sister in Sorrow - Life Histories of Female Holocaust Survivors from Hungary (Detroit, Michigan: Wayne State University Press, 2008), winner of the 2009 American Folklore Society (AFS) Elli Köngäs-Maranda professional prize for women's studies; Soul of Saul - the Life, Narrative, and Proverbs of a Transylvanian-Israeli Grandfather (Burlington, Vermont: Vermont University, 2011).

Within the last two decades, Holocaust studies have expanded to include the fields of Holocaust memory and narrative and the everyday experiences of women Holocaust survivors, in contradistinction to strictly or hard-core historical Holocaust studies of previous decades. Numerous studies of various aspects of women's post-Holocaust experiences have been conducted both in Israel (Lentin 2000; Hertzog 2006; Rosen 2006, 2008) and abroad (Heinemann 1986; Rittner and Roth 1993; Bendremer 1997; Ofer and Weitzman 1998; Tydor-Baumel 1998; Hardman 1999; Baer and Goldenberg 2003; Vasvári 2006-7, 2009). Yet, most of these studies emphasize the Holocaust period in the lives of the survivor narrators, so that the "before" and "after" time-periods remain somewhat in the shadow (Hoffman 2004). This is so largely due to the tendency "not to digress" from the Holocaust years in studies conducted before the 1990s (TydorBaumel 1997, 101), though this is less so in the recent decades.

In several research projects of female Hungarian-Jewish survivors presently living in Hungary (Budapest) and in Israel, I tried to balance this tendency by paying special attention to time divisions in the survivors' inclusive life histories including their childhood and old age (Rosen 1994, 2008). All in all, having personally met and interviewed over 100 survivors of formerly Austro-Hungarian affiliation (people from Budapest and center-State areas, Erdély/Transylvania, Slovakia, and Carpatho-Rus'), I have become closely acquainted with a relatively large sample of this group and their inclusive life experiences and 
Rosen, Ilana. “Tripping over the Dead: Hungarian-Israeli Holocaust Survivor Women's Narratives of Immigration, Restoration, and Remembrance.” AHEA: E-journal of the American Hungarian Educators Association, Volume 5 (2012): http://ahea.net/ejournal/volume-5-2012

narratives. In this essay I wish to further explore the post-Holocaust experiences of Hungarian-Israeli survivors with the emphasis on women, as their narratives proved to be more telling and detailed in terms of content, form, and mode, especially with regard to the "shadowy" time-periods of before and after the Holocaust.

In my analyses of large numbers of survivors I was able to show that although most of them emphasized the Holocaust period in their lives, many also detailed the hardships of their post-Holocaust lives as well. In most cases, the post-war time period covered the following: the first years after the Holocaust, the emigration to Israel (when relevant), marriage and child rearing, housing problems, and professional issues (more often of their husbands than their own) (Rosen 2008, 12-21; 2009, 108). Not many of the interviewees continued beyond the early 1950s in their narratives and if they did, they skimmed over the later decades before concluding with their current lives, which may be due to their mental exhaustion after relating their Holocaust experiences in detail. We find a similar phenomenon in dozens of memoirs written by Israeli Holocaust survivors, men and women alike, which feature abrupt endings around the midtwentieth century or anti-climactic continuations. Interestingly, the same phenomenon can be found in memoirs by people who went to US or France and had no national security problems like in Israel. It is as if the wind went out of them, or the very life went out of them. Yet, the unique reality which survivors faced in Israel, of a new State foundation in the framework of the Arab-Israeli conflict, requires additional exploration and clarification.

In light of the fact that the new lives of the survivors in a newly founded State were of significance in their own right, one may wonder about the "disappearance" of the rehabilitation and construction period from the inclusive life histories of survivor narrators. A close look at memoirs of pioneers and founders of the pre- and early-State period, among them (more male than female) Holocaust survivors, shows that the Holocaust is either absent from this literature or is quickly summarized in vague, token terminology ("the camps," "horrors," "There," etc.; see the exemplary book by the Sened couple 2001). In fact, people who wanted to write about both these compelling eras in their lives - the Holocaust and the founding of the new State of Israel - dedicated separate volumes to each time-period (e.g., two male survivors of Hungarian origin: Givon 1998, 2002; Ziv (Zisovits) 1992, 1996). This memoir inventory demonstrates an inability or refusal of the authors to juxtapose the two main phases of their lives, or let one include or cast a shadow over the other. The five women whose narratives are explored in this essay come from middle-class Orthodox Hungarian-Jewish families. All five were around the age of twenty in 1944 when, following the invasion of Hungary by Nazi Germany, they were deported to Auschwitz and then to various work camps and factories (Braham and Miller 2002). In the winter of 1945, as the war was nearing its end with the defeat of the German Reich, the women were marched with tens of thousands of camp prisoners in the notorious "death marches" (Krantz and Auster 1980; Bauer 1983; Krakowski 1990), and then liberated. All five moved to Israel a bit before or after the State's establishment; some married shortly before their arrival while others married soon after. Each of them had two children, a typical mini-maximal rate for survivor families, and all became grandmothers during the 1970s. Despite certain physical and psychological problems, largely all of them matured in middle-class comfort and reasonable mental stability during the closing decades of the twentieth century. When I met them in the early 1990s, they were all retirees, and one - Rosi Shakked was freshly widowed. She and Rachel Markowitz lived in the town of Petah Tikva north of Tel Aviv, whereas Dora Ashkenazi, Zsuzsa Doron, and Berta Wazner lived in the Bazera village (about halfway between Tel Aviv and Haifa); the last three were still partly involved in agricultural work on their fields or farms with their husbands.

While the five women shared general historical and socio-cultural background similarities and Holocaust-related biographies, each one had distinct features that affected her narrative. Rachel Markowitz and Dora Ashkenazi were outstandingly expressive and polyphonic. They employed a variety of languages, used humor, talked about others besides themselves, and disclosed their emotions and psychological states. While Zsuzsa Doron and Berta Wazner also attempted to reconstruct their mostly destroyed, bygone world, the mode of their narratives and narrations was less vibrant and more gloomy than those of Markowitz and Ashkenazi. Rosi Shakked's life history was a lament in many of its aspects of form and content alike, though her recent widowhood may have contributed to this tone (Rosen 2006; on atrocity as tragedy see: Greenspan 
Rosen, Ilana. "Tripping over the Dead: Hungarian-Israeli Holocaust Survivor Women's Narratives of Immigration, Restoration, and Remembrance.” AHEA: E-journal of the American Hungarian Educators Association, Volume 5 (2012): http://ahea.net/ejournal/volume-5-2012

1998, 159). The following excerpts describe focal scenes and periods in the post-Holocaust, Israeli lives of the five women and exemplify types of Holocaust repercussions in their later lives (for inclusive analyses of the five women's life histories see the following: for Doron see Rosen 1994, 123-125, 132-135; for Shakked see Rosen 2006; for Ashkenazi, Markowitz, and Wazner see Rosen 2008 ).

\section{Humble Beginnings - "We still had a sense of humor even when we had nothing else"}

The Holocaust survivors arrived at the newly founded State of Israel during the period of mass immigration [Hebrew: aliya gedola] (1948-1953) (Hacohen 2003; Lissak 2003; Goodman and Loss 2009). This was an era when immigrants streamed in from virtually all over the world, and the survivors constituted about half of the 700,000 souls that now joined the 600,000 already in Israel. Therefore, the Holocaust survivors had to cope with inevitable immigration hardships in addition to their unique suffering as survivors of ethnic cleansing (Zertal 1998; Yablonka 1999; Ofer 2009, 7; Pat 2009; Rosen 2009, 107-110; on the parallel American-Jewish experience see Mintz 2001). Invariably, studies of mass immigration mainly focus on the absorbing authorities and communities and only secondarily - and mostly in recent years - deal with the newcomers. In addition, much of this socio-historiography is nowadays directed at the condescending attitude of hegemonic Israeli institutions toward Jews from Muslim countries (Shenhav 2006; Shabi 2009). Within this explicitly post-colonialist discourse, the experiences of European Jews - mostly Holocaust survivors - were erroneously brushed aside as being less representative of immigrant exclusion and exploitation because they shared European origins with members of the absorbing authorities. Thus while it is widely known that the Oriental or mizrahi newcomers were viewed by veteran Israelis as "primitive," it is much less known that the European survivors were referred to as "human dust" whose fitness to join the Zionist enterprise was doubted (Lentin 2000, 221). In reality, like their survivor counterparts in Western countries and unlike their mizrahi counterparts in Israel, they faced the hardships of immigrants and immigration in addition to their unique predicament (Bourgignon 2005, 75-76; Lefkovitz 1997, 40; see also the recent stream of mass immigration novels written by second generation Israelis, in this case of European origin, e.g., Frenkel 2004, 2009; Frank-Mitrani 2005; Olmert 2008; Rosensher-Dolan 2009; Segal 2010). On this historical-cultural background, the following excerpts illustrate some of the experiences and conceptions of two survivor narrators.

Rachel Markowitz from Szilágysomlyo was interviewed in Petah Tikva in 1991 (in Hungarian ${ }^{1}$ ):

We moved to this nowhere; we didn't have to worry about thieves [as we had nothing at home to steal], so we went to the Sochnut [Hebrew, lit.: Agency, meaning The Jewish Agency for Israel] to ask for a job and better housing. My husband became a mechanic. He got a job in Haifa. I went to the Sochnut to look for an apartment. They told me to look for a place and then they would help me [with money]. But there were no apartments at all. Well, it is such a long story to be a new immigrant, you can't tell it all. This is in short, because it is all mixed up. In the end we found an apartment in which the water was pouring out from the wall. The apartment had one room and a common kitchen with the neighbors. We moved into this apartment. My sister wrote me from Romania and asked how we were doing with water, because they knew about the water shortage here. I wrote her that I was living in a "hole-y" place. [Biblical] Moses must have hit our wall too, because water was pouring from it... Toward Yom Kippur [the Day of Atonement on the tenth day of the month of Tishre] my sister wrote and asked how we were doing. I wrote, "We have a minister in charge of our meager supplies [Dov Yosef (1899-1980), Minister of Rationing and Supply in the first Israeli government, 1948-1949)]. Since there aren't enough chickens to give to everyone [to fulfill the tradition of kapparot, or atonement, on the Eve of Yom Kippur], the minister boards an airplane with a chicken in his arms and

${ }^{1}$ All translations of materials from my fieldwork are mine, I.R. 
Rosen, Ilana. “Tripping over the Dead: Hungarian-Israeli Holocaust Survivor Women's Narratives of Immigration, Restoration, and Remembrance.” AHEA: E-journal of the American Hungarian Educators Association, Volume 5 (2012): http://ahea.net/ejournal/volume-5-2012

together they turn in circles over us all..." You see, we still had a sense of humor even when we had nothing else.

Then we found this other apartment. But we only had twenty-four liras. Of these, I spent four and had only twenty left. To purchase the apartment, I had to go to a step uncle of mine to ask him for a loan. He said he would only give me the money if a bank would guarantee for it. I left him, hopeless. He then called me back, saying he would give me something. He was working in the Nesher [cement] factory. He said he would give me a loan from the factory account, and I would pay it back monthly. And so it was. He gave me sixty liras. Now I had eighty. I asked my aunt to lend me twenty more liras, so that now I had a hundred. Then I went to my friend Eva and told her, "get me ten liras, no matter how, just get them." It was a fortune then. From my brother I asked the remaining ten, and now I had the money for the apartment. We went to the Sochnut. They asked us if we had paid any "key-money" before. No, we hadn't. Finally we received that apartment (Rosen 2008, 183-184).

Dora Ashkenazi from Dunaszerdahely was interviewed in Bazera in 1990 (in Hebrew):

I received seven liras from the Sochnut for housing in Hadera [south of Haifa]. I spent one night there. They said it was a room with a kitchen. The room was very small, and in the corner there was a bowl. That was the kitchen! What to do now, how can I find a job here? I had a cousin in Givat Shmuel [north of Tel Aviv]. They had been here for half a year before I arrived. I decided to go to my cousin's. Next day, I traveled to Tel Aviv. I walked to tahana mercazit [Hebrew: Central Bus Station] to catch the bus to Givat Shmuel. I met my past pseudo-husband [for the emigration certificate under the British Mandate], and he told me he heard of a room that could be rented for twenty-five liras in the Montefiore neighborhood [in Tel Aviv].

Suddenly, someone calls my name, Dora Fuchs. God, I am in Israel for one day only, who would know me? In tahana mercazit, there was a small restaurant. A young man I knew in my [home]town was standing there. We had been in the same class. He came here in 1939, when I had wanted to come, too, before the War. He recognized me. I was among the first to come after the camps. Simha and sussen [Hebrew and Yiddish: great joy, in Biblical Prophetic style]. He asked me, "Where do you live?" I said, "Meanwhile, I don't have a place." I told him how I came to Israel. He said there was a man there in Montefiore Street with an apartment for rent. "Go there, look at it, and if it's any good, come back to me, and I will give you the money." I said, "Lajos, how can you? You work hard for your money." He said, "Of course I will help you, who should I help if not you?" I remember my brother [Yonah] also came with me to see the place. The room belonged to a man of Turkish origin, a bird and plant dealer. We went in. You had to go down three stairs into a yard, and then into the room. It was an elongated shabby room. The man refused to let me cook in it. I started crying, and I said to him, "Are you a Jew? How dare you be like that?" My brother already knew Hebrew so I asked him to tell the man that we are two orphans, our parents died in the camps, we have the twenty five liras and I promise not to cook anything in there. What could I have cooked? Eventually, he gave us the place for twenty five liras. I went back to Lajos and he gave me the money. I really didn't want to sell my brother's [Shlomo's] gold [coins, which he gave me before I left Europe]. I told him, "Look, Lajos, I've got some gold, but it's not mine, it's my brother's. He should be on his way here. I don't even know where he is right now. I want to give you this gold to watch over it for me, because where I live I won't be safe with strangers." 
Rosen, Ilana. “Tripping over the Dead: Hungarian-Israeli Holocaust Survivor Women's Narratives of Immigration, Restoration, and Remembrance.” AHEA: E-journal of the American Hungarian Educators Association, Volume 5 (2012): http://ahea.net/ejournal/volume-5-2012
Believe it or not, after all that, I didn't even stay in that apartment for a day. How come?
My cousin from Givat Shmuel, who was very religious, said, "I will not let you sleep there [on your own], no way." So I joined them in Givat Shmuel. They had a room and a half, with a nine-month-old baby. All I had was a Sochnut bed. I lived there for half a year, until later I found a room with my friend in Montefiore.
I, who had a profession, was the first to start working. Once in Givat Shmuel a fellow told me he read in the paper that on 20 Allenby St. [in Tel Aviv] there was a store in need of a seamstress. I went there and the owner asked me to sew something. That was the first time I worked on an electrical sewing machine, and I had problems with it, because it stopped whenever it wanted, not when I wanted it to stop. He saw all this, and despite my inexperience, he treated me to coffee in a nearby coffee shop and told me to start working the next day (Rosen 2008, 171-172).

In both women's narratives there are frequent transitions from one inadequate or "shabby" place of living to another. Nonetheless, each place costs "a fortune," whether for rent or for purchase, and each narrator achieves the needed sum in a painstaking process that involves the help of family and/or friends more than the State. The newly married Rachel Markowitz does not have to worry about thieves because there is nothing to steal from her place, which she describes as "nowhere." While her husband works in Haifa, she searches for a better dwelling. The new place is also very primitive: it has one room and a common kitchen with neighbors, and its wall drips with water. Yet, Rachel's attitude to it all - both in real time (in her letter to her sister in Romania) and in retrospect - is laced with humor. Regarding the dripping wall, she makes an allusion to the Biblical scene of Moses hitting a stone so that water should come out of it (Exodus 17, 1-8; Numbers 20, 1-13). As for the food shortages during the years of mass immigration, Rachel refers to the religious custom of kapparot in which each person "transfers" his or her sins to a chicken that is then slaughtered and donated to the poor. She jokes that due to the constraints of the austerity period and scarcity of chickens, the Minister of Rationing and Supply performs the custom collectively for the entire nation. Scarcity and shortage also govern Rachel's summary of these events. "You see, we had a sense of humor even when we had nothing else." She then shifts to the "saga" of purchasing their first apartment. In her search for loans, Rachel approaches all her relatives and even her past camp-mate Eva until she is finally able to raise the phenomenal sum of 120 Israeli liras to acquire decent housing in the northern area. (In the late 1960s they moved to Petah Tikva, the setting of her other narrative in this essay.)

Dora Ashkenazi's narrative begins with an account of the money (7 liras) she has received from the Jewish Agency to rent a house in Hadera, south of Haifa; but since she cannot find a job there ("What to do, how can I find a job here?"), she has to move southward to the area of Tel Aviv. A brother joins her in her search for an apartment and, with some gold coins given to her in Europe by another brother, plus some more money donated by a past school-mate, she is able to find another "nowhere." As in the Hadera apartment and as in Rachel's narrative, kitchen and food issues are central and problematic in this place too. If previously a bowl in the corner meant "a room with a kitchen," now the owner forbids Dora to cook in the house. The reason for this prohibition remains unclear, but the allusion to the cellar-like quality of the place ("you had to go down three stairs") may mean that it could not be properly ventilated. As a concentrationcamp survivor of just a few years, Dora feels intimidated by this restriction concerning food and - by extension - her general well-being (for survivors' long-term sensitivity to food issues see Sinler et al. 2004). She reacts with emotion and needs the help of her more veteran Israeli brother to express herself. We may note that Dora asks her brother to tell the landlord that they are two orphans whose parents died in the (concentration and death) camps, but she does not state directly that they too (the two siblings) survived these camps. Apparently, she expects no compassion from this man "of Turkish origin" and perhaps even wishes to avoid stigmatization as a Holocaust survivor and someone from the Diaspora, two of the least favorable identities of the time (Goffman 1986 [1963]; Waterson 2005, 54; Stein 2009).

After all this, "believe it or not," Dora does not remain in that place at all. As a single woman from a religious-traditional background, she accepts her cousin's objection to her living on her own and moves in with the cousin's young family in their one-and-a-half room apartment near Tel Aviv. Dora had been a 
Rosen, Ilana. "Tripping over the Dead: Hungarian-Israeli Holocaust Survivor Women's Narratives of Immigration, Restoration, and Remembrance.” AHEA: E-journal of the American Hungarian Educators Association, Volume 5 (2012): http://ahea.net/ejournal/volume-5-2012

professional seamstress since before WWII and now that she lives close to the country's center of trade and business, and is free of household duties and child rearing at this point, she ventures into the city to search for a job. Though she fails to demonstrate her sewing skills on an unfamiliar electrical sewing machine she nevertheless gets the job, which she keeps until her marriage and subsequent move to the village of Bazera.

\section{The Past Lingers on - "How can we forget?"}

The Holocaust and its horrors continue to emerge at various moments in the women's later lives, even decades afterward. The following excerpts display present-day thoughts, anguishes, fears, and deliberations of two of the narrators, as well as their realization of the incongruence of these with their everyday lives.

Rosi Shakked from Erdély was interviewed in Petah Tikva in 1991(in Hungarian):

When we came back from the camps, at first we thought, there is no God if such things could happen. But after a while, we said we should keep our faith nonetheless, perhaps not as we used to practice it, but in some way we should maintain our tradition. We now said, true that so many of us perished, there were hundreds of members in our extended family, but if even one of us survived, that in itself is a miracle.

I used to ask my husband constantly, "How could such things happen?" And he would answer, "You know that the good Lord watches over us, or else we wouldn't be here." I recently looked over our papers and documents and found this note that my husband had written, thanking God for our nice family, for their good manners, and praying that they would never suffer. He was so happy that we had a family. I would have liked to have more children but gave up the idea because I had no help. I didn't have a mother to help me. Why have many children and let them grow up in poverty? We gave everything we could to our children. They know and appreciate it.

Ever since his father died, my son suffers from high blood pressure and is under medical care. He loved his father so much. They know we always tried to give them the best, and we almost never wanted for anything. During the Six Day War [in June 1967], when I didn't know where my only son was, I was hysterical, until I finally received a letter from him. Whenever I see my children, I feel like crying because I love them so much, they are so dear to me. I have no other family. All my relatives, parents, brothers, and sister are gone. How could it happen that such a big family has perished and I am the only survivor? There were families of five and three of them survived; some had nine and four came back somehow, luck. But not one other person in my family returned, neither young nor old. Many times I've said to myself, why go on living? There's no use. But then I say that there are these children, good children, sweet grandchildren who call me every day and come to visit. They all know that this life is very hard. Our granddaughter wrote a paper on our experiences in the Holocaust. I did not tell her everything, only a little. She received a high mark and she told me, "Grandmother, I was the best in class." The boys don't ask me because they know I will immediately start crying, I am so sensitive, and it is so hard for me to speak about it. My daughter never asked me. She always says, "Mother, try to forget." I used to talk about it with my husband and ask, "How can we forget?" (Rosen 2004 Hungarian-Jewish, 58-59).

\section{Rachel Markowitz:}

That's in short. I did not tell it all, though - the great suffering. I don't know how to tell it in order, everything, all that happened. The main thing is that in the camps they tortured us, and we weren't considered human beings. Once we came back from disinfection and 
Rosen, Ilana. "Tripping over the Dead: Hungarian-Israeli Holocaust Survivor Women's Narratives of Immigration, Restoration, and Remembrance.” AHEA: E-journal of the American Hungarian Educators Association, Volume 5 (2012): http://ahea.net/ejournal/volume-5-2012

by mistake I turned my head to the other direction. I received such a blow on my head that I thought that would be the end of me. Why, what have I done? That I looked the other way? You see, it's these small things that I can't tell all of. I forget and then remember them. At night, when we went out to the toilets, we tripped over the dead and dying women. Even when we moved to Petah Tikva [in the 1960s], I still couldn't go out at night, because I was still afraid of tripping over the dead bodies. It is only since recently that I started convincing myself that it's irrational, that I should try to overcome my fear, force myself. But even now, when I walk the street in the dark, I am still afraid of tripping over the dead. You see, many of those dead or dying women in the camp were my friends and relatives (Rosen 2008, 184-185).

Both these excerpts exhibit oscillations between despair and hope, morbidity and vitality. In my detailed analysis of the life history of Rosi Shakked, I followed her constant wave-like or circular fluctuations between these two opposing urges and emotions (Rosen 2006, 42). Hope leads to moderate happiness and gratefulness for gifts of life like family and livelihood, but the very mention of these reminds the narrator of all that she lost in the Holocaust. Rosi's present family is a source of security and joy (though also of worries, for example about her soldier-son in the Six Day War). Yet, thinking of her family cannot but remind Rosi of her own childhood within an extended family of dozens of people who have all perished in the Holocaust. She was left as a sole survivor constantly mourning the loss of her relatives as well as her subsequent life without them. This tension slips through into all her references to her present family members: her husband, her son and daughter, and her grandchildren. Her husband's words - "You know that the good Lord watches over us, or else we wouldn't be here" - are partly consoling yet also provoking, because her pain is due to bereavement over the destruction of her entire core family. Rosi's children do their best to distract her from remembering and grieving about her past by calling and visiting her frequently and by openly advising her to "try to forget" (for more information about symptoms of Holocaust-survivor descendents, mainly second-generation survivors, and their attitude to their parents' suffering see: Hass 1990; Vardi 1992; Kogan 1995; Lentin 2000; Kidron 2003, 2009). From the viewpoint of the third generation such as Rosi's young granddaughter, the Holocaust and her grandmother's related experiences are a source of human empathy, intellectual interest, and even pride at mastering this knowledge ("Grandmother, I was the best in class"). Rosi's narrative and discourse reflect all these stances, but her recurrent verbal and behavioral gestures of mourning and grief (i.e., her sobbing throughout the narration and constant references to her feelings of pain and sorrow) make clear that for her there is no way out of her painful past and its never-ending remembrance.

Rachel Markowitz's description of brutal and arbitrary punishment for a minor misdeed (or for her failing to perform like a military soldier; see Primo Levi's view of the camps as a "caricature" of the German army, Levi 1988, 90) echoes Rosi Shakked's recurrent exclamations of "how" and "why," which are typical sorrowful exclamations in the literature of the ancient biblical Prophets and in the Book of Lamentations. In ancient as in post-modern times, these questions remain unanswered and even asking them becomes an act of protest. Remembrance of the painful blow plunges Rachel back into the world of camps and its horrific though routine-ized components. In the camp, Rachel's nightly routine of going out to the latrine involved tripping over the bodies of dead or dying "friends and relatives." Death became part of everyday life in the camps, or, in the words of another survivor of the Stutthof camp whose life history I documented, "At first, as was customary at home, I walked after the carriages of corpses, as in a funeral [Hebrew: levaya / halvaya, lit.: accompaniment]. But there was no end to it. The carriages multiplied and I gave up paying dignity to the dead" (Rosen 2004, In Auschwitz, 285).

With regard to Rachel, she cannot break free of the trauma of daily proximity to the dead and dying even a quarter of a century after her liberation from the camps. (On the persistent reappearances of horrific images in survivors' post-traumatic lives see: Lifton 1979, 170-171; Vansant 2001; on their attempts and dynamics of processing and alleviating trauma see LaCapra 1989; Herman 1992). Up until the 1970s and 1980s, Rachel suffered from gruesome memories when going out in the evening in the Israeli town of Petah Tikva for visits, errands, social events or even walks, because demons from her past jumped at her or rather, 
Rosen, Ilana. "Tripping over the Dead: Hungarian-Israeli Holocaust Survivor Women's Narratives of Immigration, Restoration, and Remembrance.” AHEA: E-journal of the American Hungarian Educators Association, Volume 5 (2012): http://ahea.net/ejournal/volume-5-2012

spread out under her feet. Only decades after the Holocaust, around the time of the interview in the early 1990s, does she "start convincing [her]self that it's irrational," and that she should "overcome [her] fear," and "force [her]self" out of her continuous daily nightmare.

\section{Hometown Visits -"I went back to our town, now a cursed place"}

If the previous instances of narrative and discourse of survivors demonstrated attempts to move out of the range or "radius" of the Holocaust, the following excerpts, depicting journeys to the Hungarian birthplaces of the survivor narrators, present the opposite movement: of conscious geographical and mental returns to their problematic past lives. It turns out that though these are not Auschwitz journeys (Feldman 2008), they are disconcerting and poignant in their own right.

Zsuzsa D. from Máteszálka was interviewed in Bazera in 1990 (in Hungarian):

Seven years ago I visited Hungary for the first time, to meet my sister who lives in Russia. I couldn't go to Russia to see her, but we both were able to meet in Hungary.

Unfortunately, our reunion after so many years was not successful. I felt that as we had grown older we became distant from each other, like strangers. All the love and the old memories were gone. Everything changed. She had gone to Russia and then she raised three children in Siberia, because her husband was sent there.

Last year I visited Hungary for the second time. Now for the second trip, my husband, who wanted to visit Debrecen [his hometown], joined me. The first time, seven years earlier, I kept thinking about how they had exterminated the town's Jews. But this second time was less painful. I took pictures of my childhood town and was reminded of the past, how we played as children. I wrote down my thoughts too. I wrote how I went back to our town, now a cursed place, and how I investigated the place. Seven years earlier when I went there, I kept dreaming about the deportation to the ghetto, how they had taken us from our homes. Then the dreams stopped, and I went back to this cursed town. Now the house itself wasn't there anymore, nor the business [the family's tailor workshop]. There was a highway there instead. I went into a shop and asked the young woman there if her grandmother had been born in town. She said she was not from there originally. It seemed that no one was from there "originally.

I went back to the place where the ghetto had been. Eighteen thousand people in one street, eighteen thousand Jews in one crowded street, in a town of twenty-two thousand people to begin with. What can I say? There was nothing there. Once, they took us out of the ghetto to sweep the streets, and our guard turned out to be a boy from school. Now there was nothing.

As I wrote, I reconstructed all of it: where we had lived, where we used to play, where our friends had lived. I have it all written down. I know the names of other survivors. During my second visit, my husband and I went to the local school and asked if they had pictures from my time. The headmistress said they had been sent to a museum. The school was now renamed after a Jewish man by the name of Frank. That was strange. I cried during most of our stay there, had a very bad feeling. My daughter asks me if I could visit Auschwitz, and I say, maybe, together with the future generation, with my children and grandchildren. (Rosen 2004 Hungarian-Jewish, 73-74).

Berta Wazner from Somorja was interviewed in Bazera in 1990 (in Hungarian):

My husband wanted to go there and I did not want to. When we visited the cemetery, we stayed at our friends' house. They wanted to take us out and show us around, to see things, 
Rosen, Ilana. “Tripping over the Dead: Hungarian-Israeli Holocaust Survivor Women's Narratives of Immigration, Restoration, and Remembrance.” AHEA: E-journal of the American Hungarian Educators Association, Volume 5 (2012): http://ahea.net/ejournal/volume-5-2012

and I just didn't like it... We went out to town, but I only became more tense as time went on. Finally we left for Pest, which was an enjoyable trip for me, because I did not know the city so well, so I had no bad memories. But returning to Slovakia, to the place where I had once lived - that was very hard for me... Here in Israel, I have my children and grandchildren, and my bad memories have somehow quieted down. But going back there seems to have stirred up the memories again. Sometimes at night I have terrible nightmares about the visit to the cemetery, to my poor mother's grave. I dream I cannot find her grave. In reality I did find it, only the tombstone was gone. That's because I knew that my grandparents were also buried there, side by side, and my mother was buried next to my grandmother. Once I found my grandmother's tombstone was still there, I knew that my mother's grave must be there too, but the stone was missing. Only about ten stones were still there, out of a total of about fifty or sixty graves (Rosen 2008, 214).

The hometown visit narratives of both women feature repetitions of the visit experience whether in actual, realistic terms as in Zsuzsa Doron's narrative or in a mixture of reality and nightmare as in Berta Wazner's narrative. In the 1980s Zsuzsa Doron visited Hungary twice: in 1983 and 1989. The aim of the first visit was to reunite with her sister (in her inclusive life history, Zsuzsa stressed her strong ties as a child with her three sisters in a family of seven children; see: Rosen 1994, "Appendix," 106-117). Decades after their separation following WWII and the Holocaust, the reunion with her "Soviet" sister is "not successful" and Zsuzsa feels that the two of them have become "like strangers." In addition, when viewing her hometown again after decades, Zsuzsa suffers from nightmares in which she re-lives the deportation of the town's Jews to Auschwitz. This initial experience (the failed reunion) becomes, in the framework of the narrative, a gloomy prologue for Zsuzsa's second visit to Hungary six or seven years later. This time she goes with the intention of investigation, reconstruction, and documentation of the town's Jewish past as best she can on the basis of her memory and the fresh impressions of the later visit.

To Zsuzsa's frustration, this second visit also leads to nightmarish discoveries of loss and disappearance. First, the area of her childhood home and the family business has been turned into a highway, a void. Second, she tries unsuccessfully to locate someone of her generation or the following generation in the town. In her quest she approaches a random shopkeeper but the shopkeeper and - so it seems to Zsuzsa everyone around her all belong to the "after the deluge" generation (Genesis 10,1). The third site is the town's ghetto, the "locale" of her nightmares during and after her first visit of 1983. At the time of incarceration in the ghetto in 1944, even a random guard watching over the ghetto Jews who were ordered "to sweep the streets" turns out to be an acquaintance, "a boy from school." But now "there is [simply] nothing [and no one] there."

Fourth and last is the town's school. Zsuzsa tries to find a remnant of her past life in the graduationclass pictures that schools habitually preserve and display. But the pictures of her time have "been sent to a museum," though the school is now re-named "after a Jewish man by the name of Frank." All these unsuccessful or aborted searches distress and sadden her, "I cried during most of our stay there, had a very bad feeling." Nevertheless Zsuzsa succeeds in reviving at least the image or mental picture of her childhood town by writing down her memories and taking pictures of the town's sites. These verbal and visual acts of reconstruction offer her partial consolation and relief from the pain of remembrance and loss (LaCapra 1999).

Berta Wazner reluctantly joins her husband to visit Somorja and - more lightheartedly - [Buda]Pest. In her hometown, all she wants is to find the grave of her mother, who died before the deportations. Though the tombstone is gone, Berta is able to locate her mother's burial spot once she finds the graves of her maternal grandparents, as her mother was buried next to her mother's mother. Apart from the graveyard, Berta can hardly bring herself to go and see other sites in town as this is very painful for her: "I only became more tense as time went on," since "going back there has stirred up the memories again." In addition, Berta has nightmares in which, unlike in reality, she fails to find her mother's grave. Behind the agony about her mother's death and grave lurk Berta's memories of deportation - much like Zsuzsa Doron's nightmares regarding her deportation from Máteszálka - which took place soon after Berta’s mother's death. Both 
Rosen, Ilana. "Tripping over the Dead: Hungarian-Israeli Holocaust Survivor Women's Narratives of Immigration, Restoration, and Remembrance.” AHEA: E-journal of the American Hungarian Educators Association, Volume 5 (2012): http://ahea.net/ejournal/volume-5-2012

women find that they must summon all their strength to face their past hometowns, with sites that still exist as with those that have vanished. This is very different from the reconciled re-visit of historian Shimon Redlich to his hometown of Brzezany (Redlich 2004, 275). Berta only finds some respite when she leaves Somorja for Pest, as she has no personal war memories of Pest, and finally once back in Israel where she is surrounded by her family, and where the "bad memories somehow quiet[ ] down".

In their hometown visit narratives, both women specifically refer to their "children and grandchildren" though none of these actually joined them on the visits. Zsuzsa Doron includes her future generations in her reply to her daughter's suggestion to visit Auschwitz in her old age. Zsuzsa says she would be willing to do that only if she would be surrounded by her offspring (her daughter and son and maybe their children), thus proving that not only has she survived but also produced future generations. In the end, as described in a modest family booklet created by Zsuzsa's daughter Dvora Manor, they did make the trip to Auschwitz in the mid-1990s, but that visit was already under the shadow of Zsuzsa's fatal illness (Manor [no details]). Thus Zsuzsa's earlier comment regarding the potential hardships of a journey to the death camps and her need for her children's support become prophetic in a sense that none of them could foresee.

For Berta as well, the close proximity of her offspring becomes a source of strength, stability, and reassurance - though on a day-to-day basis rather than on a journey to Auschwitz. Berta refers to her "children and grandchildren" in the context of what I described as the fragile balance she maintains between memory and forgetfulness, expression and suppression (Rosen 2008, 123-124). However, once she separates herself from her familiar surroundings of "here in Israel" with "my children and grandchildren" for the trip to Slovakia, this balance is shaken. At that point, the memory of the Holocaust with its flesh-and-blood figures, places, events, and tribulations takes stronger hold of her life than she can bear. It is then and there that she, like Zsuzsa Doron, is inflicted with nightmares of death and loss. While Zsuzsa responds by embarking on intensive documentation of her past life in town, Berta achieves some relief by leaving it all behind her and visiting Budapest, where she views more positive recreations of her past Hungarian life and culture.

\section{Conclusion: Haunted Ever After}

In this essay I presented a few significant excerpts from the life histories of five Israeli women of Austro-Hungarian origin in which they talk about the Holocaust and its later reverberations in their lives. These narratives deal with three themes in the post-Holocaust lives of the narrators: the hardships of beginning a new life in a new country; the recurrence - or rather the ever-presence - of Holocaust flashbacks and nightmares throughout their lives; and impressions from the women's visits to their past Hungarian hometowns in their later years. It turns out that despite its ubiquitous hardships, the period of immigration and absorption of the mid-twentieth century is remembered and recounted in a light and occasionally humorous tone. Processes such as starting a family, locating and funding reasonable housing, and finding employment are often described in tedious detail (e.g. the accumulation of specific sums of money and the identities of friends and family who gave or lent the requisite sums), all for the sake of showing that the narrators somehow finally achieved these basic goals.

In the early State period during which these procedures took place, shortage and deprivation were shared by all, including Holocaust survivors, so that their unique struggles become somehow intermeshed into that of a stressful yet heroic epoch. Decades afterward, when these women survivors have become mothers and grandmothers to generations of accomplished Israelis (Lentin 2000) and live in relative comfort harvesting a life-time's hard work, they are still psychologically burdened by the memories of their suffering in the Holocaust and the loss of their beloveds. Rosi Shakked cannot enjoy her present family without immediately thinking of her entirely annihilated nuclear family; or, she fluctuates between appreciating the "miracle" or "luck" of her own survival and mourning the loss of her extended childhood family members. Similarly, Rachel Markowitz can barely break free of the images of dead bodies even in her sheltered life in the center of Israel as late as the 1980s and 1990s.

Despite obvious obstacles and pervasive hardship, it seems that all five women Holocaust survivors somehow manage to maintain a bearable balance between their past and present, their annihilated childhood 
Rosen, Ilana. "Tripping over the Dead: Hungarian-Israeli Holocaust Survivor Women's Narratives of Immigration, Restoration, and Remembrance.” AHEA: E-journal of the American Hungarian Educators Association, Volume 5 (2012): http://ahea.net/ejournal/volume-5-2012

families and their present ones, and between bereavement and acceptance, or even hope (Rosen 2006, 4347). On this backdrop, the visits of two of them to their original hometowns including the sites of their deportation to Auschwitz mark the point at which this tenuous equilibrium is disrupted. Zsuzsa Doron faces ghost-town experiences in her hometown of Máteszálka (incidentally the hometown of the parents of American actor Tony Curtis, né Bernard Schwartz). Yet she cleverly transforms her sorrowful experience into a project of re-construction and documentation of her past community. Similarly, Berta Wazner hurries to leave her hometown of Somorja with its intrusive, painful memories for the sake of a more enjoyable "cultural" trip to Budapest. (For all five women in this essay, who lived in more remote areas in the historical Austro-Hungarian Empire, the capital is a central-European cultural tourist destination; this is not at all the case for Jews who actually lived there before and during WWII; see: Rosen 2008, 58-81). As for the five female narrators, their decades-long life in Israel with their three generational extended families represents an anchor of rehabilitation, overcoming of hardship, and reassurance. But this is true only as long as they master their memories (or "try to forget"), cling to their "children and grandchildren," and frontally face their fear of "tripping over the[ir] dead" and vanished past.

\section{Works Cited}

Baer, Elizabeth Roberts and Myrna Goldenberg, eds. (2003). Experience and Expression - Women, the Nazis, and the Holocaust. Detroit, Michigan: Wayne State UP.

Bauer, Yehuda (1983). "The Death Marches, January-March 1945." Modern Judaism

$3.1,1-21$.

Bendremer, Jutta T. (1997). Women Surviving the Holocaust in Spite of the Horror. Lewiston, New York: Edwin Mellen P.

Bourguignon, Erika (Winter 2005). "Memory in an Amnesic World: Holocaust, Exile, and the Return of the Suppressed." Anthropological Quarterly 78.1 Bringing the Past into the Present: Family Narratives of Holocaust, Exile, and Diaspora, 63-88.

Braham, Randolph L. and Scott Miller, eds. (2002). The Nazis' Last Victims - The Holocaust in Hungary. Detroit, Michigan and Washington: Wayne State UP and the U.S. Holocaust Memorial Museum.

Feldman, Jackie (2008). Above the Death Pits, beneath the Flag - Youth Voyages to Poland and the Performance of Israeli National Identity. New York: Berghahn Books.

Frank-Mitrani, Rina (2005). Kol bayit tsarikh mirpeset [Every House Needs a Porch]. Tel Aviv: Yediot Ahronot, Hemed, 2005.

Frenkel, Alona (2004). Yalda [Childhood]. Tel Aviv: Mappa. . (2009). Na'ara [Teen Years]. Tel Aviv: Am Oved.

Givon, Yosef (1998). Sipurim hungariyim [Hungarian Stories]. Tel Aviv: Yaron Golan. . (2002). Regavim shel akhzava [Clods of Disappointment]. Tel Aviv:

Halonot.

Goffman, Erving (1986 [1963]). Stigma: Notes on the Management of Spoiled Identity. New York: Touchstone.

Goodman, Yehuda and Joseph Loss (Summer 2009). "The Other as Brother: Nation Building and Ethnic Ambivalence in Early Jewish-Israeli Anthropology." Anthropological Quarterly 82.2, 477-508.

Greenspan, Henry (1998). On Listening to Holocaust Survivors: Recounting and Life History. Westport, Connecticut and London: Praeger.

Gutman, Israel, ed. in chief. Encyclopedia of the Holocaust, 4 vols. New York: Macmillan.

Hacohen, Dvora, ed. (2003). Immigrants in Turmoil - Mass Immigration to Israel and its Repercussions in the 1950s and after (trans. Gila Brand). Syracuse, New York: Syracuse UP. Hardman, Anna (1999). "Representations of the Holocaust in Women's Testimony," 
Rosen, Ilana. “Tripping over the Dead: Hungarian-Israeli Holocaust Survivor Women's Narratives of Immigration, Restoration, and Remembrance.” AHEA: E-journal of the American Hungarian Educators Association, Volume 5 (2012): http://ahea.net/ejournal/volume-5-2012

Leak, Andrew and George Paizis, eds., The Holocaust and the Text-Speaking the Unspeakable.

London and New York: Macmillan P. Ltd., 51-66.

Hass, Aaron (1990). In the Shadow of the Holocaust - The Second Generation. Ithaca:

Cornell UP.

Heinemann, Marlene Eve (1986), Gender and Destiny: Women Writers and the

Holocaust. New York: Greenwood P.

Hertzog, Esther, ed. (2006). Nashim u-mishpaha ba-shoa [Women and Family in the

Holocaust]. Tel Aviv: Otsar Ha-Mishpat.

Herman, Judith Louise (1992). Trauma and Recovery. New York: Basic Books.

Hoffman, Eva (2004). After Such Knowledge: Memory, History, and the Legacy of the Holocaust. New York: Public Affairs.

Kidron, Carol A. (Dec. 2003). "Surviving a Distant Past: A Case Study of the Cultural

Construction of Trauma Descendant Identity." Ethos 31.4, 513-544.

. (Feb. 2009). "Toward an Ethnography of Silence - The Lived

Presence of the Past in the Everyday Life of Holocaust Trauma Survivors and their Descendants in Israel." Current Anthropology 50.1, 5-27.

Kogan, Ilany (1995). The Cry of the Mute - A Psychoanalytic Perspective of the

Second Generation. London: Free Association Books.

Krakowski, Shmuel. "Death Marches," Gutman, Israel, ed. in Chief, Encyclopedia of the Holocaust. New York: Macmillan, 348-354.

Krantz, Morris with Louis Auster (1980). Hitler's Death Marches. New York:

Kensington.

LaCapra, Dominick (1989). Writing History, Writing Trauma. Ithaca: Cornell UP. . (Summer 1999). "Trauma, Absence, Loss." Critical Inquiry 25, 696-727.

Lefkovitz, Lori Hope (Winter 1997). "Inherited Holocaust Memory and the Ethics of Ventriloquism." The Kenyon Review, New Series 19.1, 34-43.

Lentin, Ronit (2000). Israel and the Daughters of the Shoah-Reoccupying the Territories of Silence. New York: Berghahn Books.

Levi, Primo (1988). The Drowned and the Saved (trans. Raymond Rosenthal). London: M. Joseph.

Lifton, Robert J. (1979). The Broken Connection - On Death and the Continuity of Life. New York: Simon and Schuster.

Lissak, Moshe (2003), "The Demographic Social Revolution in Israel in the 1950s." Journal of Israeli History vol. 22.2, 1-31.

Mintz, Alan (2001). Popular Culture and the Shaping of Holocaust Memory in America. Seattle and London: Washington UP.

Ofer, Dalia (Summer 2009). "The Past That Does Not Pass: Israelis and the Holocaust Memory." Israel Studies 14.1, 1-35.

Ofer, Dalia and Lenore J. Weitzman, eds. (1998). Women in the Holocaust. New Haven: Yale UP.

Olmert, Aliza (2008). Ein Stück vom Meer: Roman (trans. Jean-Luc Allouche). Paris: Denoël.

Patt, Avinoam (2009). Finding Home and Homeland - Jewish Youth and Zionism in the Aftermath of the Holocaust. Detroit, Michigan: Wayne State UP.

Redlich, Shimon (2004). "Returning to the Shtetl." Polin: Studies in Polish Jewry 17, 267-275.

Rittner, Carol and John K. Roth, eds. (1993). Different Voices: Women and the Holocaust. New York: Paragon Books.

Rosen, Ilana (1994). Sho'ah be-merkaz ha-hayim - nituah folkloristi shel sipure hayim mi-pi nitsole sho'ah dovre hungarit [The Holocaust at the Center of Life - a Folkloristic Analysis of Life Histories Told by Hungarian Speaking Holocaust Survivors] (Ph.D. Dissertation). Jerusalem: Hebrew U. Central Library. 
Rosen, Ilana. "Tripping over the Dead: Hungarian-Israeli Holocaust Survivor Women's Narratives of Immigration, Restoration, and Remembrance.” AHEA: E-journal of the American Hungarian Educators Association, Volume 5 (2012): http://ahea.net/ejournal/volume-5-2012

(2004). Be-Auschwitz takanu be-shofar-yotse karpatorus mesaprim al

ha-sho'ah [In Auschwitz We Blew the Shofar - Carpatho-Rusyn Jews Remember the Holocaust]. Jerusalem: Yad Vashem and the Avraham Harman Institute for Contemporary Jewry at Hebrew U. . (2004). Hungarian-Jewish Women Survivors Remember the Holocaustan Anthology of Life Histories. Lanham, Maryland: University Press of America. . (2006). "Holocaust Memory and Narrative as Lament: Narratives of

Hungarian Female Survivors." Journal of Indian Folkloristics 8.1-2, 29-52. . (2008). Sister in Sorrow - Life Histories of Female Holocaust Survivors from Hungary. Detroit, Michigan: Wayne State UP. . (2009). "Personal Historical Narrative Shaping the Past and the Present." European Journal of Jewish Studies 3.1, 103-133.

Rozensher-Dolan, Tzipora (2009). Anahnu nanuah [We Shall Rest]. Or Yehuda: Zmora-Bitan.

Segal, Daniela (2010). Lifamim ze matsliah [Sometimes it Works]. Ben Shemen: Modan.

Sened, Yonat and Alexander (2001). Adama lelo tsel [Earth without a Shadow]. Jerusalem: Ariel.

Shabi, Rachel (2009). Not the Enemy - Israel's Jews from Arab Lands. New Haven: Yale UP.

Shenhav, Yehuda (2006). The Arab Jews: A Postcolonial Reading of Nationalism, Religion, and Ethnicity. Stanford, California: Stanford UP.

Sinler, Amy J, Nancy S. Wellman, and Oren Baruch Stier (2004). "Holocaust Survivors Report Long-Term Effects on Attitude toward Food." Journal of Nutrition, Education, and Behavior 36.4, 189-199.

Stein, Arlene (Winter 2009). "As Far as They Knew I Came from France - Stigma, Passing, and Not Speaking about the Holocaust." Symbolic Interaction 32.1, 44-60.

Tydor-Baumel, Judith (1998). Double Jeopardy: Gender and the Holocaust. London and Portland, Oregon: Valentine Mitchell.

Vansant, Jacqueline (2001). Reclaiming Heimat - Trauma and Mourning in Memoirs by Jewish Austrian Re-émigrés. Detroit, Michigan: Wayne State UP.

Vardi, Dina (1992). Memorial Candles - Children of the Holocaust. London:

Tavistock / Routledge.

Vasvári, Louise O. (2006-7). "Women's Holocaust Memories: Trauma, Testimony, and the Gendered Imagination." Kovács, András and Michael I. Miller, eds. Jewish Studies.

Budapest: Central European UP, 141-154. . (2009). "Emigrée Central European Jewish Women's Holocaust

Life Writing," Vasvári, Louise O. and Steven Tötösy de Zepetnek, eds. Comparative Central European Holocaust Studies. West Lafayette: Purdue UP, 158-172.

Vasvári, Louise O. and Steven Tötösy de Zepetnek, eds. (2009). Comparative Central European Holocaust Studies. West Lafayette: Purdue UP.

Waterson, Allisse (Winter 2005). "An Anthropology of Violence, Dispossession, and

Diaspora." Anthropological Quarterly 78.1 Bringing the Past into the Present: Family Narratives of Holocaust, Exile, and Diaspora, 43-61.

Yablonka, Hanna (1999). Survivors of the Holocaust: Israel after the War (trans. Ora Cummings). Basingstoke, England: Macmillan Publishers.

Zertal, Idith (1998). From Catastrophe to Power-Holocaust Survivors and the Emergence of Israel. Berkeley, California: California UP.

Ziv (Zisovits), Moshe (1992). Kaftorim ba-marak: sipuro shel nitsol mi-Bukhenvald

[Buttons in the Soup: a Buchenwald Survivor's Story]. Tel Aviv: Milo. . (1996). Kan lo hayu trombonim [Here There Were No

Trombones]. Tel Aviv: Milo. 